Agro-Science Journal of Tropical Agriculture, Food, Environment and Extension Volume 9 Number 1 January 2010 pp. $38-46$

ISSN 1119-7455

\title{
SPATIAL DEPENDENCE OF SOME PHYSICAL PROPERTIES OF A TYPIC PLITHAQAUALF ON THE BASEMENT COMPLEX IN SOUTHWESTERN NIGERIA
}

\author{
Obi $^{1}$, J. C., Awonuga ${ }^{2}$, A. O. and Umeojiakor ${ }^{2}$, A. O. \\ ${ }^{1}$ Department of Soil Science, University of Uyo, Uyo, Nigeria. \\ ${ }^{2}$ Department of Agronomy, University of Ibadan, Ibadan, Nigeria.
}

\begin{abstract}
Knowledge of soil physical and chemical properties is a key to making agronomic and environmental decisions. The objective of this study was to assess the extent of spatial dependence and spatial structure of some soil physical properties and implications on pedogenesis and management in the basement complex soils of southwestern Nigeria. Surface soil $(0-15 \mathrm{~cm})$ samples were collected at $10 \mathrm{~m}^{2}$ rigid grid intervals in a 0.5 hectare plot under fallow along Parry road in University of Ibadan. Classical statistics and geostatistics were adopted in analysis of data. Among the nine measured soil physical properties, sand, coarse sand and bulk density were least variable with coefficient of variation $(\mathrm{CV})<15 \%$. Moderately variable $(\mathrm{CV} \geq 15 \leq 35 \%)$ properties included clay, silt, silt + clay and silt/clay ratio (SCR), whereas fine sand and saturated hydraulic conductivity were highly variable (CV >35\%). The nugget to sill ratio showed that clay (12.5\%), silt (9.9\%), fine sand (17.0\%), silt + clay (5.4\%), SCR (25.7\%), bulk density (18.1\%) and hydraulic conductivity (12.2\%) were strongly spatially dependent, while total sand (40.4\%) and coarse sand (29.2\%) contents were moderately spatially dependent indicating intrinsic variation attributable to soil particle size and mineralogy. Pearson correlation coefficients of the semivariances of the soil

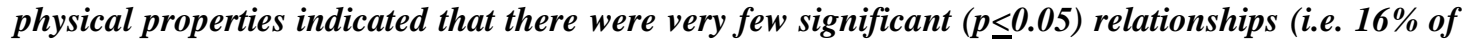
the soil physical property pairs). It was observed that those semivariances that displayed significant correlation with each other had similarity in the appearance of their contour maps. The implication is that significantly correlated variables could be representative for site specific agronomic and environmental management and for study of pedogenesis.
\end{abstract}

Keywords: Spatial dependence, spatial variability, soil physical properties, pedogenesis,

\section{INTRODUCTION}

Knowledge of soil physical and chemical properties is a key to making agronomic and environmental decisions. But soil properties have been found to be heterogeneous from global scale to changes in structural and chemical composition of soil minerals on microscale (FAO, 1974; Sawhney, 1977). Soil variability is a product of soil forming factors that interact over a continuum of spatial and temporal scales. The precision of statements that could be made about soil properties and management for sustainable food and fiber production at any location, therefore, depends largely on the amount of variation existing within the area sampled. Many authors have emphasized that the interpolation of results of agronomic experiments is often difficult because of local variability that could lead to large variation among replications of experimental treatments (Brouwer and Bouma, 1997; Brouwer, et al., 1993; Wendt et al., 1993; Manu et al., 1996).
It is generally recognized that soil properties manifest both long and short range variability and are multivariate in nature (Nielsen et al. 1973, Russo and Bresler, 1981). This variability can be studied using analysis of variance (ANOVA), in which case a small number of randomly collected samples may provide useful mean comparisons among site/agronomic variables. Ranking of coefficient of variation (CV) of soil properties into different classes including least $(<15 \%)$, moderately $(15-35 \%)$, and highly $(>35)$ variable according to Wilding (1985), can also be used. But neither ANOVA nor CV accounts for spatial covariance structures of multivariate soil properties (Nielson et al., 1995). Geostatistics is a valuable tool for analyzing spatial variability, interpolating between observations and ascertaining the interpolated values with specified error using a minimum number of observations (Burrough, 1991). Spatial statistical analyses are ideal for investigating spatial covariance structure 
of soil properties, understanding soil forming factors, genetic processes and development of farm management strategies (Trangmar et al., 1985). This study, therefore, assesses the extent of spatial dependence and spatial structure of some soil physical properties and their implications on pedologenesis and management of basement complex soils of southwestern Nigeria.

\section{MATERIALS AND METHODS Description of the study area}

The study was conducted on a 0.5 hectare (100m by $50 \mathrm{~m}$ ) fallow plot located by the side of Parry road on the north-west end of the University of Ibadan in southwestern Nigeria. University of Ibadan is located approximately between longitudes $3^{\circ} 44^{\prime}$ and $4^{\circ} 00^{\prime} \mathrm{E}$ and latitudes $7^{\circ} 25^{\prime}$ and $7^{\circ} 30^{\prime} \mathrm{N}$. The climate of Ibadan area is hot subhumid and lies within the derived savanna zone. Mean annual rainfall is about $1200 \mathrm{~mm}$ within the rainy season occurring between April and November. The mean monthly temperature ranges between $24^{\circ} \mathrm{C}$ and $28^{\circ} \mathrm{C}$. The sampling site is gently undulating with slope of about $4-6 \%$. The soils are derived from coarse granite gneiss of the precambarian basement complex. The dominant plant species in the study area include Chromlaena odorata, Azadirachta indica, Eleasis guineansis, Gliricidia sepium, Cynodon dactylon, Panicum maximum and Penissetum purpureum.

\section{Soil sampling and laboratory analysis}

The study site is at the lower slope position that experiences seasonal fluctuation of water table and classified as Typic Plithaqaualf. Surface soil samples $(0-15 \mathrm{~cm}$ depth $)$ were collected at grid nodes along transects made at $10 \mathrm{~m}$ intervals in a rigid grid format with the aid of Dutch auger. Soil samples were processed and the analyses performed included particle size distribution using hydrometer method (Gee and Bauder, 1986), bulk density using core method (Blake and Hartage, 1986) and saturated hydraulic conductivity (Klute and Dirksen, 1986).

\section{Statistical analysis}

Measured variables in the data set were analyzed using classical statistical methods to obtain the minimum, maximum, mean, median, standard deviation, skewness, kurtosis and correlation analysis (SAS Institute, 1996). The degree of spatial variability for each variable was determined by geostatistical methods using semivariogram analysis and kriging (Trangmar et al., 1985; Bailey and Gatrell, 1998; McBratney and Pringle, 1999). The assumption of classical statistics is that variation of soil properties is randomly distributed within the units, but many soil properties are continuous variables whose values at any location can be expected to vary according to direction and distance of separation from neighboring samples. Then, spatial dependence was studied using the semivariogram. Semivariance was calculated using:

$$
\gamma(h)=\frac{1}{2 N(h)} \sum_{i=1}^{N}\left[Z\left(x_{i}\right)-Z\left(x_{i}+h\right)\right]^{2}
$$

where $\mathrm{h}$ is the lag distance

$$
\gamma(h) \text { is the semivariance at lag } \mathrm{h} \text {, }
$$

$\mathrm{Z}$ is a random variable (value of soil property),

$\mathrm{Z}\left(\mathrm{x}_{\mathrm{i}}\right)$ is random variable for a fixed location $\mathrm{x}_{\mathrm{i}}$,

$\mathrm{N}(\mathrm{h})$ is the number of pairs of values $\mathrm{Z}\left(\mathrm{x}_{\mathrm{i}}\right)$,

$\mathrm{Z}\left(\mathrm{x}_{\mathrm{i}}+\mathrm{h}\right)$ separated by a vector $\mathrm{h}$.

Schematic representation of ideal and experimental semivariogram plots are shown in Figures 1 and 2 respectively. In semivariogram plots the semivariance increases with distance between sampling location, rising to a constant value that approximates the sill at a given separation distance called the range of spatial dependence (a). Ideally, the experimental semivariogram should pass through the origin as shown in Figure 1 when the separation distance is zero, but soil properties display non-zero semivariance as the separation distance tends to zero. The nugget variance or nugget effect $\left(\mathrm{C}_{0}\right)$ shown in Figure 2 represents unexplained or random variance frequently caused by measurement error or microvariability of the property which cannot be detected at the scale of sampling. Semivariograms were drawn and fitted with several different models. The best fit model was selected with weighted least square regression (SAS Institute, 1996). The semivariograms were fitted to either a linear

$$
\begin{aligned}
& \text { for } \mathrm{h} \leq \mathrm{a} \\
& \gamma(h)=C_{0}+C_{1} \text { for } \mathrm{h}>\mathrm{a}
\end{aligned}
$$

or spherical model, which is

$$
\begin{aligned}
& \text { for } \mathrm{h} \leq \mathrm{a} \\
& \qquad \gamma(h)=C_{0}+C_{1}\left[\frac{3 h}{2 a}\right] \\
& \text { for } \mathrm{h}>\mathrm{a}
\end{aligned}
$$

where $C_{0}$ is the nugget effect,

$C_{l}$ is the structural variance,

$a$ the range of spatial dependence and

$C_{0}+C_{l}$ is the sill

Distinct classes of spatial dependence for the soil properties were obtained by the ratio of the nugget to sill. If the ratio was $<25 \%$, between 25 and $75 \%$ or $>75 \%$, the variable was considered strongly, moderately or weakly spatially dependent respectively (Cambardella, et al., 1994). On the semivariances of the soil physical properties, Pearson correlation analysis was performed (SAS 
Institute, 1996). Finally contour maps of each variable were created through ordinary kriging (David, 1977; Journel and Huijbregts, 1978; and Clark, 1979) using their respective semivariogram models in Spatial Module of S-Plus (S-Plus, 1997).

\section{RESULTS AND DISCUSSION Variation of soil properties}

The Pearson correlation among soil physical properties studied showed that clay content significantly $(\mathrm{p}<0.01)$ correlated with sand $(\mathrm{r}=0.53)$, silt + clay $(\mathrm{r}=0.57), \mathrm{SCR}(\mathrm{r}=0.54)$ and bulk density ( $\mathrm{r}=-0.36)$ (Table 1$)$. Silt significantly correlated with sand $(\mathrm{r}=0.87, \mathrm{p}<0.01)$, silt + clay $(\mathrm{r}=0.93, \mathrm{p}<0.01)$, silt/clay ratio $(\mathrm{r}=0.63, \mathrm{p}<0.01)$ and bulk density $(\mathrm{r}=0.34, \mathrm{p}<0.05)$. Sand significantly correlated with silt + clay $(\mathrm{r}=-0.93$, $\mathrm{p}<0.01)$, SCR $(\mathrm{r}=-0.33, \mathrm{p}<0.05)$ and bulk density $(\mathrm{r}=-0.42, \mathrm{p}<0.01)$. Fine sand significantly correlated with coarse sand $(\mathrm{r}=-0.88, \mathrm{p}<0.01)$, while silt + clay significantly correlated with SCR $(\mathrm{r}=0.34, \mathrm{p}<0.05)$ and bulk density $(\mathrm{r}=-0.42$, $\mathrm{p}<0.01)$. Saturated hydraulic conductivity did not significantly correlate with any of clay, silt, sand, fine sand, coarse sand, silt + clay, silt clay ratio (SCR) and bulk density. Duffera et al. (2007) reported significant correlation between particle sizes, their derivatives and solute transport in soils (Strock et al. 2001). The consistent significant correlations between sand and silt or clay observed in this study were indications that it plays important role in development of the soil and could be a major factor to be considered in management. The mean and median values were used as primary estimates of central tendency, and standard deviation, coefficient of variation $(\mathrm{CV})$, minimum, maximum, skewness and kurtosis were used as estimates of variability (Table 2). Despite skewness and kurtosis of distribution of the soil physical properties studied, the mean and median values were similar with the median either slightly less than or higher than the mean. These indicated that outliers did not dominate the measure of central tendency. Shulka et al. (2004 a and b), Iqbal et al. (2005), Obi and Ogunkunle (2009) reported similarity of means and median values of soil physical, chemical and biological properties and for grain and biomass yield. Among the nine measured soil physical properties, sand, coarse sand contents and bulk density were least variable with CVs of $4.6 \%, 11.9 \%$ and $6.4 \%$ respectively. Moderately variable soil physical properties (i.e. CV $>15<35 \%$ ) included clay $(24.3 \%)$, silt $(27.4 \%)$, silt + clay $(21.9 \%)$ and silt clay ratio $(28.4 \%)$, whereas fine sand $(47.5 \%)$, and saturated hydraulic conductivity $(59.1 \%)$ were highly variable $(\mathrm{CV}>35 \%)$. The fact that the study site was at the lower slope position and continually enriched with materials from the higher positions of the toposequence may be responsible for least to moderate variability within the single field plot studied. This assertion was further confirmed by the high silt / clay ratio that ranged between 0.48 and 3.33 compared to $<0.15$ (Young, 1976) indicating that the soil is not highly weathered. It was reported that coefficient of variation of soil particle sizes ranged from least to moderately variable whereas that of saturated hydraulic conductivity was highly variable (Shulka et al. 2004 a and b, Obi and Ogunkunle, 2009 and Botros et al. 2009). Generally, the descriptive statistics showed moderate soil variability in the study area, but could not discriminate between intrinsic (natural as a result of factors of soil formation) and extrinsic (imposed by management and land use) sources of variation. Therefore, spatial dependence of the soil properties was also investigated using geostatistics.

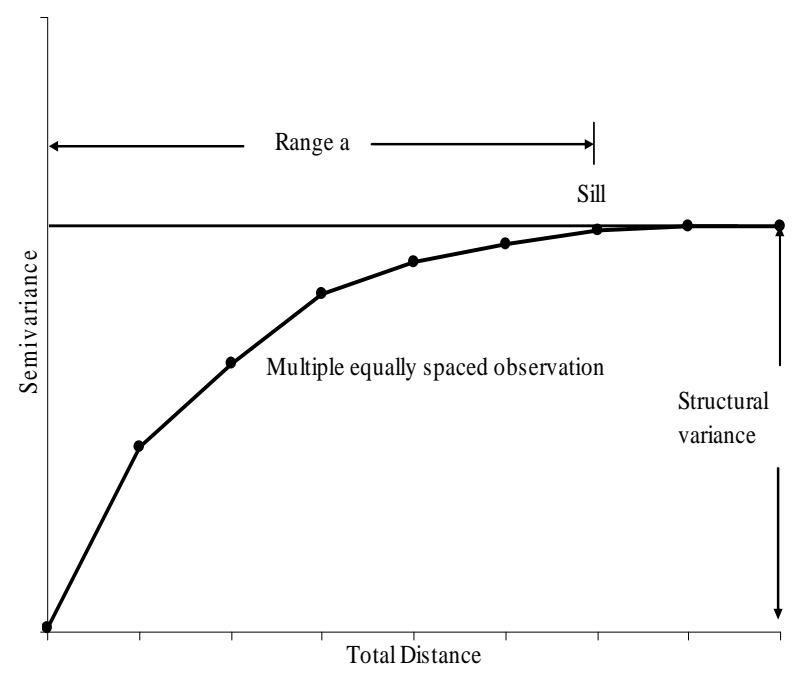

Fig. 1: Ideal semivariogram with zero nugget variance

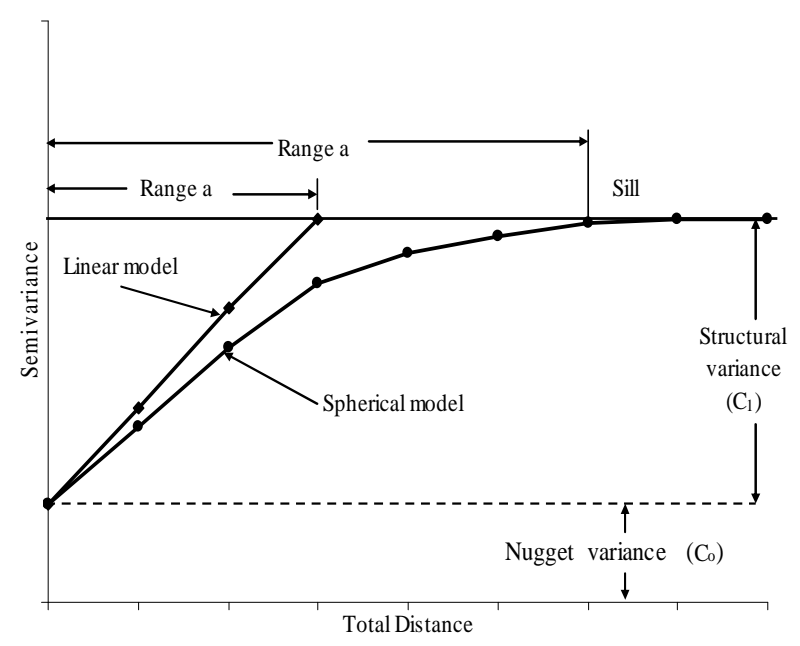

Fig. 2: Experimental semivariogram with nugget variance 
Table 1: Pearson correlation coefficient of soil physical properties

\begin{tabular}{|c|c|c|c|c|c|c|c|c|}
\hline & Clay & Silt & Sand & Fine sand & Coarse sand & Silt + clay & Silt/clay ratio & Bulk density \\
\hline Silt & 0.25 & & & & & & & \\
\hline Sand & $-0.53 * *$ & $-0.87 * *$ & & & & & & \\
\hline Fine sand & -0.13 & -0.18 & 0.21 & & & & & \\
\hline Coarse sand & -0.12 & -0.24 & 0.27 & $-0.88 * *$ & & & & \\
\hline Silt + clay & $0.57 * *$ & $0.98 * *$ & $-0.93 * *$ & -0.20 & -0.25 & & & \\
\hline Silt/clay ratio & $-0.54 * *$ & $0.63^{* *} *$ & $-0.33^{*}$ & 0.10 & -0.06 & $0.34 *$ & & \\
\hline Bulk density & $-0.36^{* *}$ & $-0.34 *$ & $0.42^{* *} *$ & 0.22 & -0.01 & $-0.42 * *$ & 0.03 & \\
\hline Ksat & -0.14 & -0.15 & 0.16 & 0.15 & -0.07 & -0.18 & -0.05 & 0.03 \\
\hline
\end{tabular}

Table 2: Descriptive statistics of the particle size distribution of soils

\begin{tabular}{|c|c|c|c|c|c|c|c|c|c|}
\hline & & Mean & Median & Min. & Max. & $\mathrm{CV}$ & Std. dev. & Skewness & Kurtosis \\
\hline Clay & & 54.4 & 62.0 & 42.0 & 102.0 & 24.3 & 13.2 & 1.03 & 1.88 \\
\hline Silt & 1 & 112.8 & 100.0 & 40.0 & 220.0 & 27.4 & 30.9 & 1.11 & 2.68 \\
\hline Sand & $\mathrm{gkg}^{-1}$ & 831.6 & 838.0 & 698.0 & 787.0 & 4.6 & 38.6 & 1.31 & 2.04 \\
\hline Fine sand & & 165.0 & 179.0 & 6.0 & 292.0 & 47.5 & 78.4 & -0.44 & -0.98 \\
\hline Coarse sand & & 666.5 & 630.0 & 518.0 & 848.0 & 11.9 & 79.4 & 0.62 & -0.50 \\
\hline Silt + clay & | & 167.1 & 162.0 & 122.0 & 300.0 & 21.9 & 36.6 & 1.42 & 2.86 \\
\hline Silt/clay ratio & & 2.15 & 1.93 & 0.48 & 3.33 & 28.4 & 0.61 & 0.14 & 0.05 \\
\hline Bulk density & $\mathrm{g} \mathrm{cm}^{-3}$ & 1.79 & 1.81 & 1.49 & 1.97 & 6.4 & 0.11 & -0.84 & 0.34 \\
\hline Ksat & $\mathrm{cm} \mathrm{h}^{-1}$ & 3.68 & 3.39 & 1.36 & 12.09 & 59.1 & 2.17 & 1.93 & 5.50 \\
\hline
\end{tabular}

Ksat - Saturated hydraulic conductivity

\section{Spatial dependence of soil physical properties}

The semivariance statistics of measured soil properties are shown in Table 3. Several models were fitted to the semivariograms and linear model was obtained as the best fit. Anisotropy was not evident in the directional semivariograms for any of the properties. Therefore, isotropic models were fitted using weighted least square regressions. The entire semivariogram (Figures 3 - 5) models displayed positive nugget effect which may be as a result of sampling error, random, inherent variability or short range variability. Spatial dependence which implied the relative sizes of the nugget effects among different measured soil physical properties can be described by expressing the nugget variance as a percentage of total semivariance or sill (Trangmar et al. 1985). Clay, silt, fine sand, silt + clay, SCR, bulk density and hydraulic conductivity were strongly spatially dependent (i.e. $<25 \%$ ), whereas total sand and coarse sand contents were moderately spatially dependent $(>25<75 \%)$. None of the soil properties measured was weakly spatially dependent. Strong to moderately spatial dependence of particle-size distribution had been attributed to intrinsic variation in soil texture and mineralogy and hence to soil formation processes Cambardella et al. 1994; Shukla. et al. 2004a) The linearity of semivariograms coincided with the analogy presented by Trangmar et al., (1985) showing that single, long range process dominated the soil formation process. Pearson correlation coefficients of the semivariance of the soil physical properties studied indicated that there were very few significant $(\mathrm{p} \leq 0.05)$ relationships (i.e. $16 \%$ of the soil physical property pairs). Thus, Pearson correlation analysis may not give adequate information on the relationship or trend of distribution of these properties in soils of basement complex parent materials.

\section{Kriging}

The result of contour maps (kriging) indicated that in spite of the few relationships established with the Pearson correlation among the semivariances of the measured soil physical properties, those that displayed significant correlation with each other equally had similarity in the appearance of their contour maps (Figures 3 - 5). The significantly correlated soil physical 
clay

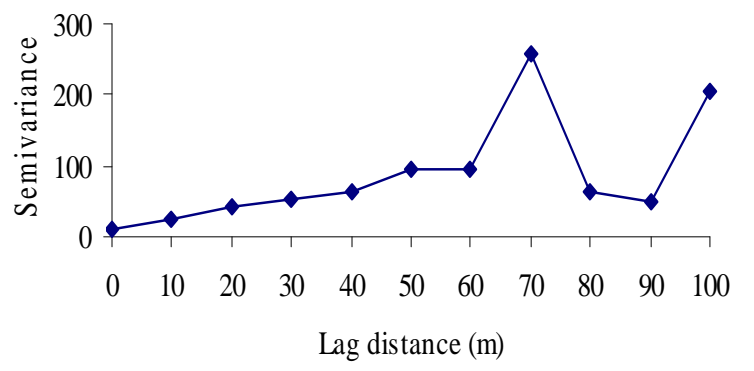

silt

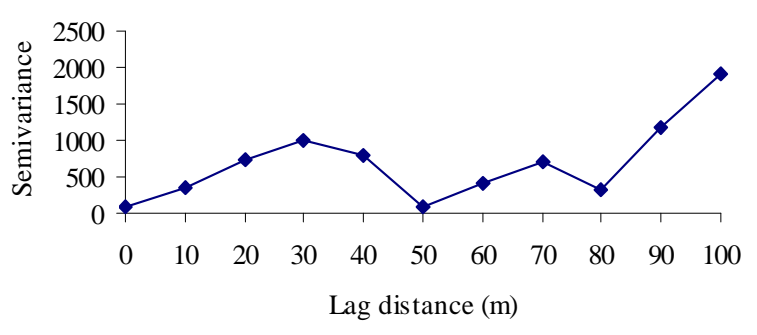

sand

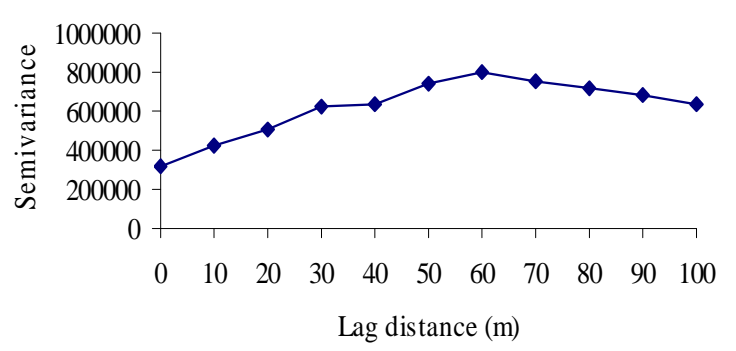

Clay $\left(\mathrm{g} \mathrm{kg}^{-1}\right)$

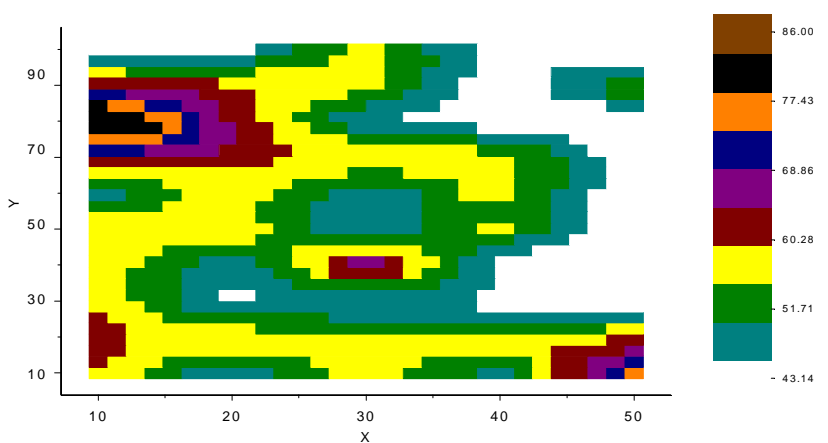

Silt $\left(\mathrm{g} \mathrm{kg}^{-1}\right)$

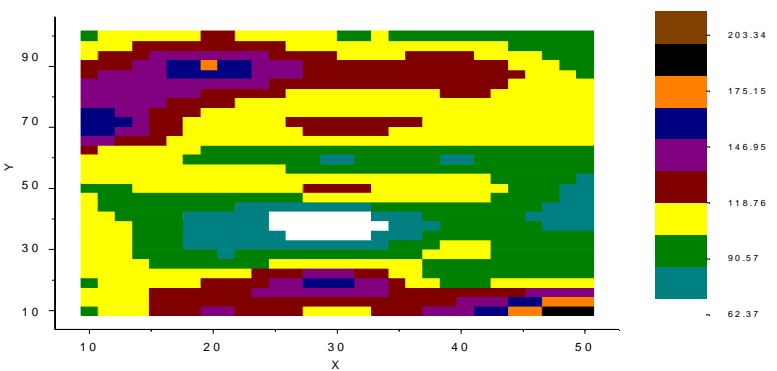

Sand $\left(\mathrm{g} \mathrm{kg}^{-1}\right)$

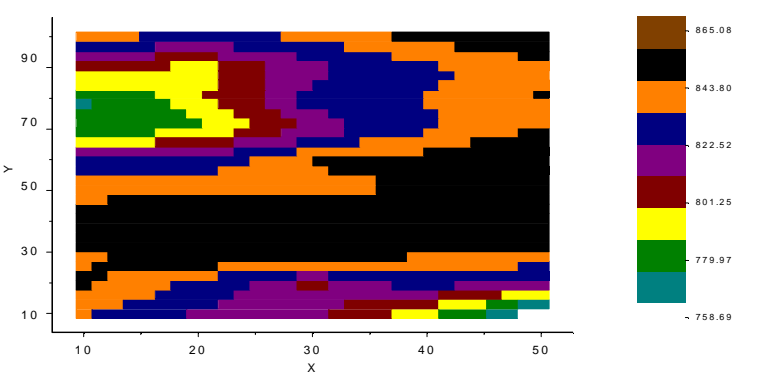

Fig 3: Semivariograms and kriged maps of clay, silt and sand contents of the study area

Table 3: Semivariance statistics of the soil physical properties

\begin{tabular}{llllllllll}
\hline & Clay & Silt & Sand & Fine sand & Coarse sand & Silt + clay & Silt clay ratio & Bulk density & Ksat \\
\hline Nugget & 12.0 & 94.0 & 322146.0 & 1264.0 & 1846.0 & 92.0 & 0.102 & 0.0026 & 0.195 \\
Sill & 96.0 & 944.0 & 796400.0 & 7400.0 & 6320.96 & 1701.0 & 0.414 & 0.014 & 1.13 \\
Range & 50.0 & 32.6 & 60.0 & 50.0 & 80.0 & 60.0 & 70.0 & 100.0 & 70.0 \\
Co/Co+C & 12.5 & 9.9 & 40.4 & 17.0 & 29.2 & 5.4 & 24.7 & 18.12 & 12.21 \\
R & 0.79 & 0.76 & 0.57 & 0.52 & 0.26 & 0.36 & 0.51 & 0.79 & 0.76 \\
\hline
\end{tabular}

Ksat - saturated hydraulic conductivity

Table 4: Pearson correlation coefficient of Semivariance of the soil physical properties

\begin{tabular}{lllllllll}
\hline & Clay & Silt & Sand & Fine sand & Coarse sand & Silt + clay & Silt/clay ratio & Bulk density \\
\hline Silt & -0.08 & & & & & & & \\
Sand & 0.03 & -0.58 & & & & & & \\
Fine sand & -0.43 & 0.06 & 0.07 & & & & & \\
Coarse sand & -0.41 & 0.29 & -0.06 & $0.85^{* *}$ & & & & \\
Silt + clay & 0.35 & $0.84^{* *}$ & $-0.65^{*}$ & -0.19 & 0.01 & & & \\
Silt/clay ratio & 0.14 & $0.88^{* *}$ & -0.44 & 0.05 & 0.24 & $0.74^{*}$ & & \\
Bulk density & $0.69^{*}$ & 0.14 & -0.24 & -0.55 & -0.53 & 0.58 & 0.06 & \\
Hydraulic conductivity & 0.25 & 0.16 & 0.38 & 0.05 & 0.23 & -0.01 & 0.27 & \\
\hline
\end{tabular}


Fine sand

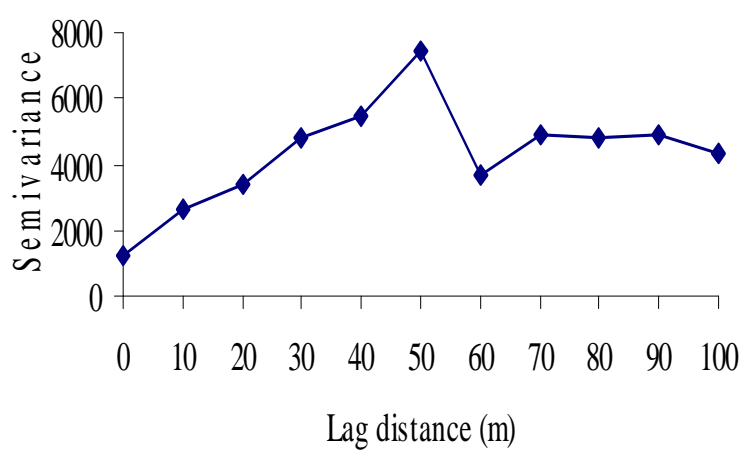

Coarsesand

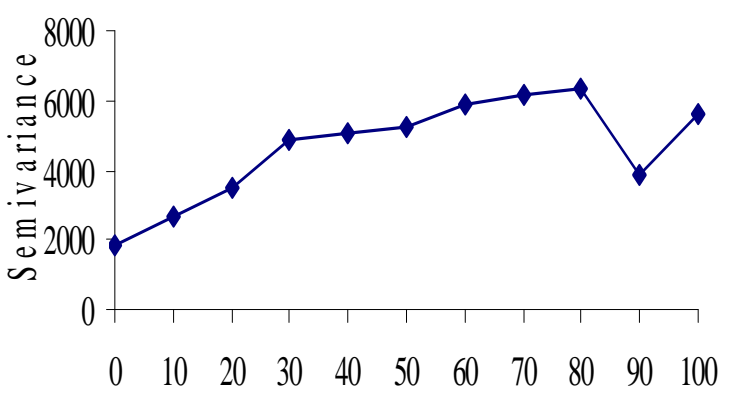

Lag distance (m)

silt + clay

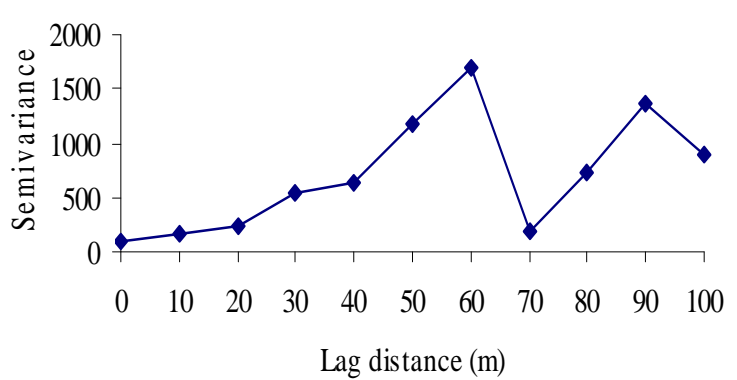

Fine sand $\left(\mathrm{g} \mathrm{kg}^{-1}\right)$

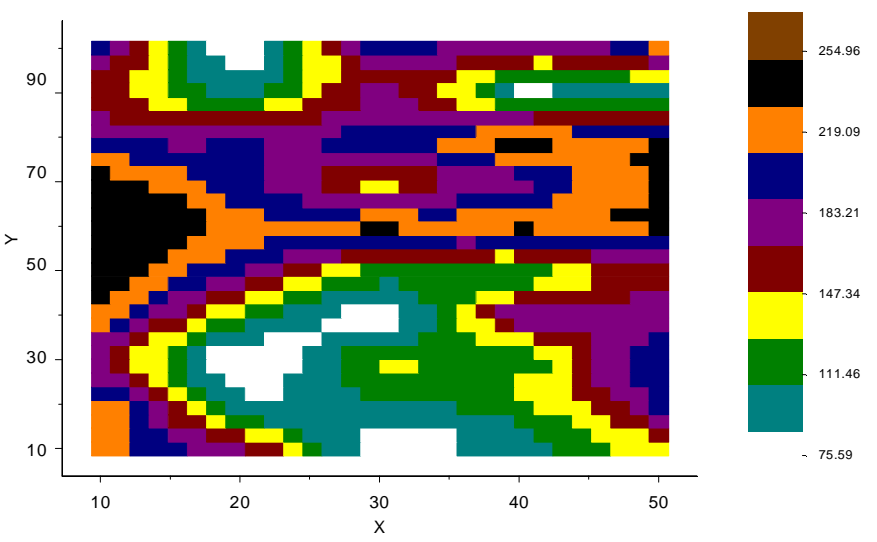

Coarse sand $\left(\mathrm{g} \mathrm{kg}^{-1}\right)$

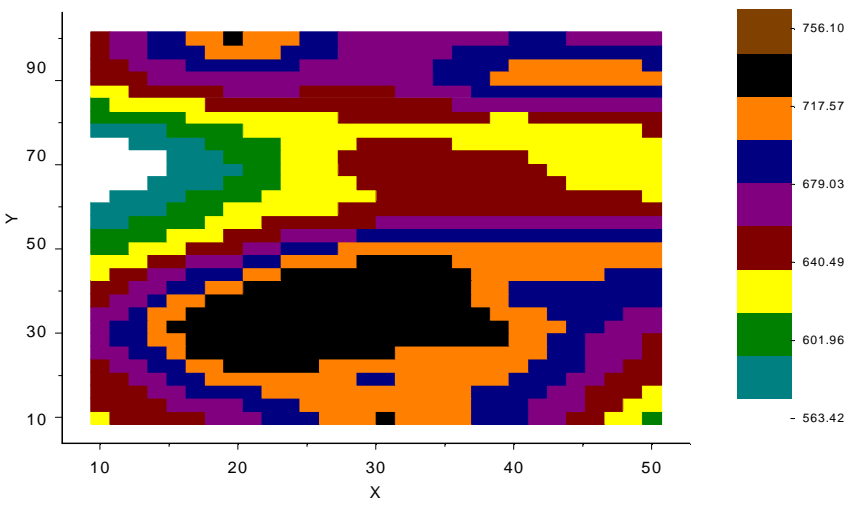

Silt + clay $\left(\mathrm{g} \mathrm{kg}^{-1}\right)$

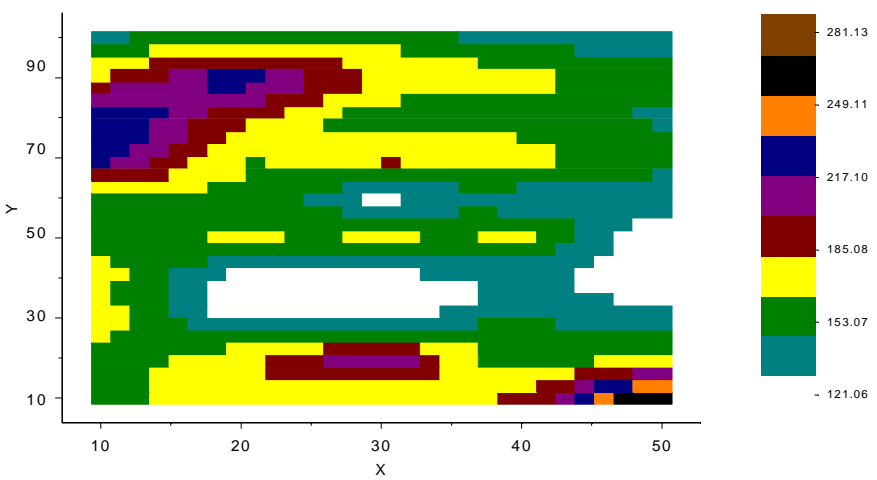

Fig 4: Semivariograms and kriged maps of fine sand, coarse sand and clay + silt contents of the study area 
Obi, J. C., Awonuga A. O. and Umeojiakor, A. O.

SCR

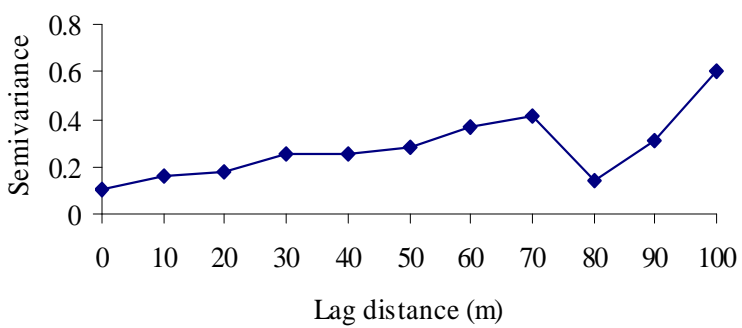

Bulk density

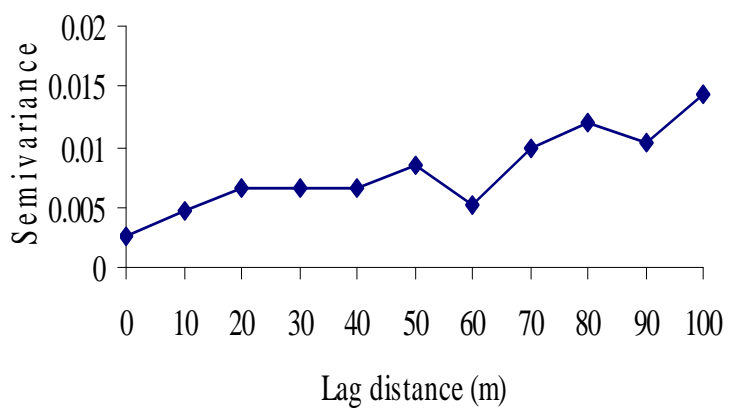

Hydraulic conductivity

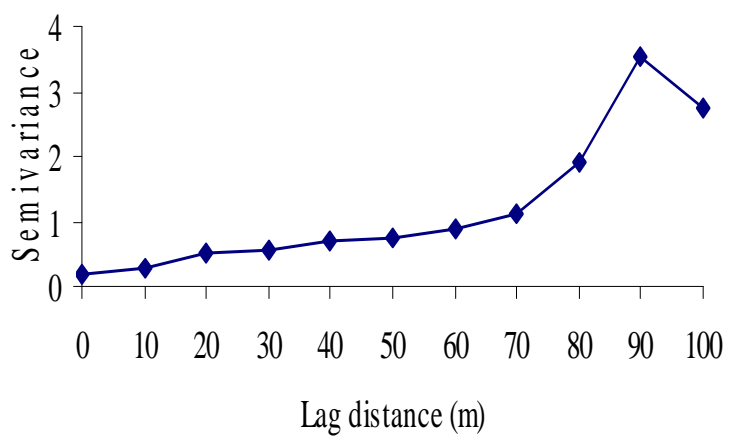

SCR

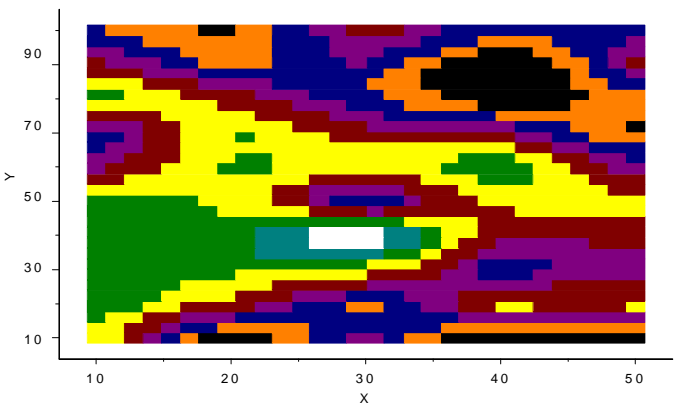

Bulk density $\left(\mathrm{g} \mathrm{cm}^{-3}\right)$

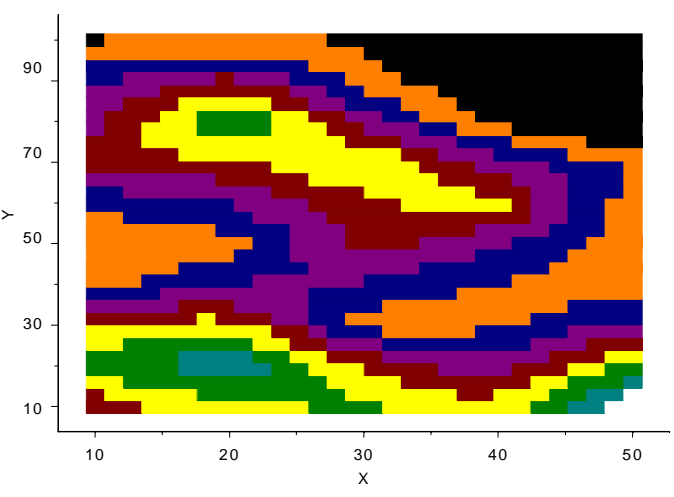

Hydraulic conductivity $\left(\mathrm{cm} \mathrm{min}^{-1}\right)$

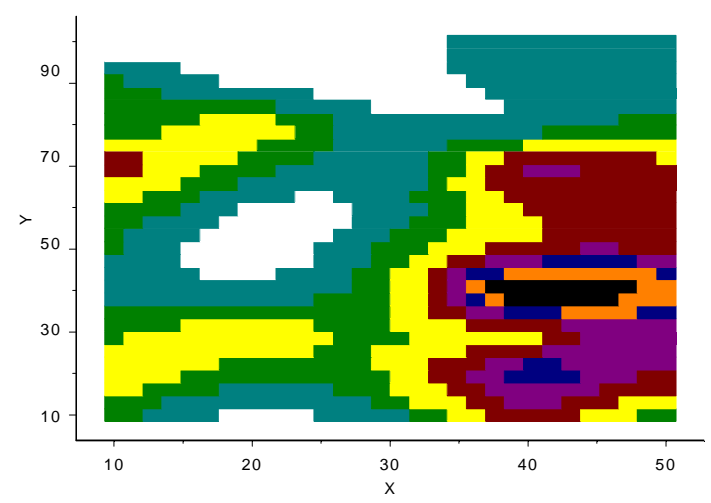

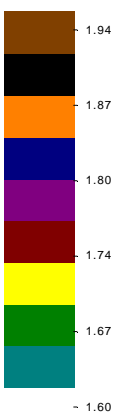

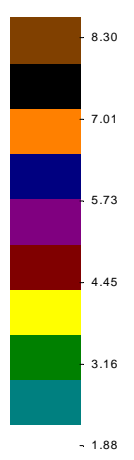

Fig 5: Semivariograms and kriged maps of silt/clay ratio (SCR), bulk density and saturated hydraulic conductivity of the study area 
property pairs (Table 4) included clay and bulk density $(\mathrm{r}=0.69, \mathrm{p}<0.05)$, silt and silt + clay $(\mathrm{r}=$ $0.84, \mathrm{p}<0.01)$, SCR $(\mathrm{r}=0.88, \mathrm{p}<0.01)$, sand content and silt + clay $(\mathrm{r}=-0.65 . \mathrm{p}<0.05)$, fine sand and coarse sand $(\mathrm{r}=0.85, \mathrm{p}<0.01)$ and silt + clay and $\operatorname{SCR}(\mathrm{r}=0.70, \mathrm{p}<0.05)$. There were indications that the correlation of semivariance statistics could express possible relationships among soil property pairs. Therefore, their contour maps could have implications for variable rate application of fertilizer, water, seed rate etc. (Iqbal et al., 2005). The implication is that significantly correlated or intercorrelated variables could be represented by a single or few variables for site-specific management and study of peodgenesis. Iqbal et al., (2005) observed that differential water holding capacity of different textures combined with uniform application of irrigation water during the growing season of cotton led to either over or under application of water and variability in cotton lint yield.

\section{CONCLUSIONS}

The mean and median values of the soil physical properties studied were similar with the median being either slightly less than or higher than the mean indicating that outliers did not dominate the measure of central tendency despite skewness and kurtosis of distribution. Among the nine measured soil physical properties, the least variable coefficient of variation values $(\mathrm{CVs})$ were for total sand, coarse sand and bulk density. Moderately variable values were obtained for clay, silt, silt + clay and silt / clay ratio (SCR), while fine sand and saturated hydraulic conductivity were highly variable. The nugget to sill ratio showed that clay, silt, fine sand, silt + clay, SCR, bulk density and saturated hydraulic conductivity were strongly spatially dependent, while total sand and coarse sand contents were moderately spatially dependent indicating intrinsic variation attributable to soil texture and mineralogy. Pearson correlation coefficients of the semivariance were significant in $16 \%$ of the soil physical property pairs studied. There were indications that the correlation of semivariance statistics could express possible relationships among soil property pairs and their contour maps could actually be utilized for management decision processes. It was observed that those that displayed significant correlation with each other equally had similarity in the appearance of their contour maps. The implication is that significantly correlated variables could be useful in site specific agronomic and environmental management decision processes and study of pedogenesis.

\section{REFERENCES}

Bailey, T.C., and Gatrell, A. C. 1998. Interactive spatial data analysis. Addison Wesley Longman, UK.

Blake, G. R. and Hartage , K. H. 1986. Bulk density. In Methods of soil analysis. Part 1. A. Klute (ed.). ASA Monogr. No. 9. Madison, WI. Pp. 363 - 376.

Botros, F. E., Harter, T, Onsoy, Y. S., Tuli, A. and Hopmans, J. W. 2009. Spatial variability of hydraulic properties and sediments characteristics in a deep alluvial unsaturated zone. Vadose Zone J. 8:276289.

Brouwer, J. and Bouma, J. 1997. Soil and crop growth variability in the sahel: highlights of research (1990-1995) at ICRISAT Sahelian centre. Information Bulletin 49. ICRISAT, Patanchewru Andrah Pradesh, India.

Brouwer, J., Fussel, L. K. and Hermann 1993. Soil and crop growth variability, Microvariability in the West African semiarid tropics: a possible risk-reducing factor for subsistence farmers. Agriculture, ecosystem and environment 45: 229-238.

Burrough, P. A. 1991. Sampling designs for quantifying map unit composition. In Spatial Variabilities of Soils and Landforms. M.J. Mausbach and L. P. Wilding (eds) SSA. Special Publication No. 28. Soil Science Society of America Journal Madison, WI. pp. 89-127.

Cambardella, C. A., Moorman, T. B., Novak, J. M., Parkin, T. B., Karlan, D. L., Turcp, R. F. and Konopka, A. E. 1994. Field scale variability of soil properties in central Iowa Soil Science Society of America Journal. 58:1501-1511.

Clark, I. 1979. Practical Geostatistics. Applied Sci. Publ., London.

David, M. 1977. Geostatistics area reserve estimation. Elsevier Sci. Publ., Amsterdam.

Duffera, M. White, J. G. and Weisz, R. 2007. Spatial variability of southeastern U. S. Coastal Plain Soil physical properties: implication for site specific management. Geoderma 137:327 - 339.

FAO 1974. Soil Map of the World. Vol. 1. Legend. UNESCO, Paris.

Gee, G.W., and Bauder, J.,W. 1986. Particle size analysis. p. 404-407. In A. Klute (ed.) Methods of soil analysis. Part 1. 2nd ed. Agron Monogr. 9. ASA and SSSA, Madison, WI.

Iqbal, J., Thomasson, J. A, Jenkins, J. N., Owens, P. R and Whisler, F. D. 2005. Spatial variability analysis of soil physical 
Obi, J. C., Awonuga A. O. and Umeojiakor, A. O.

properties of alluvial Soil Science Society of America Journal 69:1338 - 1350.

Journel, A.G., and Huijbregts, C. J. 1978. Mining geostatistics. Academic Press, London.

Klute A. and Dirksen, C. 1986. Hydraulic conductivity and diffusivity: Laboratory methods. P.687 - 784. In Methods of soil analysis. Part 1. Physical and mineralogical methods. 2nd ed. Agron. Monogr. 9. ASA and SSSA. Madison, WI.

McBratney, A. B., and Pringle, M. J. 1999. Estimating average and proportional variograms of soil properties and their potential use in precision agriculture. Precis. Agric. 1:219-236.

Manu, A., Pfordresher, A. A., Geiger, S. C., Wilding, L. P. and Hossner, L. R.. 1996. Soil parameters related to crop growth variability in Western Niger, West Africa. Soil Science Society of America Journal 60: 283-288.

Nielsen, D. R., Bigger, J. W. and Erh, K. T. 1973. Spatial variability of field measured soil water properties. Hilgandia 42: 215-259.

Obi, J. C. and Ogunkunle, A. O. 2009. Influence of termite infestation on the spatial variability of soil properties in the guinea savanna region of Nigeria. Geoderma, 148: $357-368$.

Russo, D. and Bresler, E. 1981. Soil hydraulic properties as stochastic processes: I. An analysis of field variability. Soil Science Society of America Journal 45: 682-687.

SAS Institute. 1996. SAS systems for information delivery for Windows. Release 6.12. SAS Inst., Cary, NC.

Sawhney, B. L. 1977. In. "Minerals in Soil Environment" J. B. Dixon and S. B. Weeds. (eds.). Soil Sci. Soc. Am. Madison, Wisconsin. 405 - 434.

Shukla, M. K. Lal, R. and Ebinger, M. 2004b Principal component analysis for predicting biomas and corn yield under different land uses. Soil Science 169: 215224.
Shukla, M. K. Slater, B, K., Lal, R. and Cepuder, P. 2004a. Spatial variability of soil properties and potential management classification of a chernozemic field in lower Austria. Soil Science 169: 852-860.

S-Plus. 1997. S-Plus SpatialStats user's manual for Windows and Unix. Data Analysis Product Division, MathSoft, Seattle, WA.

Strock, J. S., Cassel, D. K. and Gumpertz, M. L. 2001. Spatial variability of water and bromide transport through variably saturated soil blocks. Soil Science Society of America Journal 65: 1607 - 1617.

Trangmar, B. B., Yost, R. S. and Uehara, G. 1985. Application of geostatistics to spatial studies of soil properties. Advances in Agronomy. Vol. 38: 45-94.

Wendt, J. W., Barrada, A. Gaoh, M. G. and Schulze, D. G. 1993. Phosphorus sorption characteristics of productive and unproductive Niger Soil Science Society of America Journal 57 (3): 766-773.

Wilding, L. P. 1985. Spatial variability: Its documentation, accommodation, and implication to soil surveys. In Soil spatial Variability. D. R. Nielsen and J. Bouma (eds). Pudoc. Wageningen, The Netherlands, pp. 166-194.

Young, A. 1976. Soil survey and land evaluation in developing countries. A case study of Malawi. Geo. J. 143:407-431. 